\title{
Treatment of pulp and paper mill effluent using low cost adsorbents: An overview
}

\section{Shaveta Kakkar*}

Avantha Centre for Industrial Research and Development, Paper Mill Campus, Yamuna Nagar (Haryana), India

Anju Malik

Department of Energy and Environmental Sciences, Chaudhary Devi Lal University, Sirsa (Haryana), India

Sanjeev Gupta

Aditya Birla Water Application and product development Centre, Grasim Industries Limited, Vilayat Industrial Estate, Bharuch (Gujrat)

${ }^{*}$ Corresponding author. E-mail:shaveta27@gmail.com

\begin{abstract}
In the present review, the suitability of adsorption process using low cost adsorbent for the treatment of pulp and paper mill effluent has been discussed. It is clear that adsorption processes are appropriate for the removal of recalcitrant compounds such as surfactants and pesticides, among others biodegradable or non-biodegradable compound present in pulp and paper mills effluents. The importance of the adsorption is to improvement of the removal of various physico- chemical (biological oxygen demand (BOD), chemical oxygen demand (COD), colour, suspended solids, lignin), heavy metals ( $\mathrm{Cu}$, $\mathrm{Cr}, \mathrm{Fe}, \mathrm{Zn}, \mathrm{Ni}$ and $\mathrm{Mn}$ etc) organochlorine compounds, all recalcitrant pollutant, reduce toxicity, enhance colour removal by using different cost effective adsorbents. The effective use of the different adsorbents developed from different adsorbent media such as activated carbon, agriculture by product and industrial wastes and sludge as adsorbents for the removal of different pollutants from the various processes and operations of pulp and paper mill as potential alternatives to different treatment process and received widespread attention. Adsorption necessity is a novel treatment option to improve the efficiency of removal within the discharge limits of wastewaters into the receiving bodies without causing any damage of the environment. However, still there is a need to find out the practical usefulness of such low cost adsorbent at industrial scale with the special reference to metals.
\end{abstract}

Keywords: Adsorption, Adsorbent, Agriculture waste materials, Pulp and paper mill effluent

\section{INTRODUCTION}

Industrialization has resulted in the formation of huge amount of waste products, which are released into the environment in the form of wastewater leading to environmental pollution and deterioration. The amounts of industrial wastes that cause the pollution interference with the best usage of the receiving water have initiated with the turn of the twentieth century (Nemerow 2007). The increasing public awareness of the fate of pollutants and stringent regulations recognized by the several authorities and agencies are pushing the industry to treat effluents to the required compliance level before discharging in to the environment (D'Souza et al., 2006). The environmental pollution by pulp and paper industry are not limited by wastewater generation, solid wastes including sludge generating from wastewater treatment plants and air emissions and other prob-

\section{Article Info}

DOI:10.31018/jans.v10i2.1769

Received: January 24, 2018

Revised: March 23, 2018

Accepted: May 5, 2018

\section{How to Cite}

Kakkar, S. et al. (2018).

Treatment of pulp and paper mill effluent using low cost adsorbents: An overview. Journal of Applied and Natural Science, 10(2): 695 - 704 
Table 1. Potential pollutants from pulp and paper mills (Ali and Sreekrishnan, 2001).

\begin{tabular}{ll}
\hline Types of pollutants & Typical example and sources \\
\hline Gases & Malodorous gases e.g. $\mathrm{H}_{2} \mathrm{~S}$ and mercaptain from Kraft pulping and recovery process- \\
& es Oxides of sulfer e.g. $\mathrm{SO}_{2}$ and $\mathrm{SO}_{3}$ from recovery furnaces and lime kilns. \\
Effluents & Suspended solids including bark particles fiber pigments, dirt from debarking. \\
& Dissolved colloidal organics e.g. hemicellulose, sugars, sizing agents \\
& Chromotophores mainly lignin compounds \\
& Chlorinated compounds from bleach plants \\
& Dissolved organics, e.g. $\mathrm{NaOH}, \mathrm{Na}_{2}, \mathrm{Na}_{2} \mathrm{SO}_{2}$ \\
& Tharmal loads \\
Particulates & Fly ash from coal fired power boilers \\
Solid wastes & Char from bark burners \\
& Sludges from primary and secondary treatment and recovery section \\
& Solids such as grit, bark and other mill solid wastes \\
\hline
\end{tabular}

Table 2. Physical-chemical properties of wastewater of paper mill along with WHO permissible limits (1995), for the release of treated wastewater to irrigation waterway (Farhan et al., 2013).

\begin{tabular}{|c|c|c|c|}
\hline Parameters & $\begin{array}{l}\text { Characteristics of } \\
\text { wastewater }\end{array}$ & $\begin{array}{l}\text { Characteristics after } \\
\text { treatment }\end{array}$ & $\begin{array}{l}\text { WHO permissi- } \\
\text { ble limits }\end{array}$ \\
\hline $\mathrm{pH}$ & 6.39 & 6.9 & $6.8-8.5$ \\
\hline Color & Dark brown & Colorless & \\
\hline Temperature (o C) & 30 & Ambient temperature & 20 \\
\hline Total solids (mg/l) & 6810 & $>100$ & 655 \\
\hline Total dissolved solids (mg/l) & 3080 & $>70$ & 450 \\
\hline Total suspended solids (mg/l) & 3720 & $>32$ & 200 \\
\hline Chemical oxygen demand (mg/l) & 1640 & $>147.6$ & 300 \\
\hline
\end{tabular}

expected to reach up to 9.3 billion (United $\mathrm{Na}$ tions, 2011) and the world may be under great fresh water inadequacy in near future. Therefore, the removal of toxic organic and inorganic pollutants from wastewater is important in the present scenario (Ali et al., 2012).Pollutants which are released during several process of pulp and paper production can be reduced by adopting several internal treatment methods, improvements, especially in combination with management measure of the industry (Kamali and Khodaparast, 2015).

The characteristics of the effluents to be treated depends on the type of wood, the nature of process, the quantity of water that the mill is able to circulate, the technology used and the selected management practices. Depending on the raw material and the process involved in pulp and paper mill, untreated waste effluents can have high biochemical oxygen demand (BOD), chemical oxygen demand (COD) (1640 mg/l), solids (6810 $\mathrm{mg} / \mathrm{l})$ dissolved solids $(3080 \mathrm{mg} / \mathrm{l})$ suspended solids (mainly fibers) $(3720 \mathrm{mg} / \mathrm{l})$, fatty acids, tannins, resin acids, lignin, and its derivatives. Certain pollutants are naturally arising and others are xenobiotics, which are formed during the pulp and paper manufacturing process (Area and Valade, 1998; Ali and Sreekrishnan, 2001 and Farhan et al., 2013).

According to Ahmad and Hameed (2010); ElAshtoukhy et al. 2008; Gong et al. (2008), various methods have been employed for waste water treatment, activated carbon adsorption was found to be superior for wastewater treatment compared to other physical and chemical techniques, as they possess inherent limitations such as high cost, formation of hazardous by-products and intensive energy requirements, activated carbon has emerged as a potential alternative to conventional physiochemical technologies in wastetreatment facilities. Adsorption process is very effective method in terms of cost, flexibility, simplicity of design, and ease of operation compared to other techniques. It does not result in the formation of harmful substances (Rafatullah et al.

Table 3. Alternative feedstock's proposed for the preparation of activated carbon (Mohanand Pittman, 2007) .

\begin{tabular}{ll}
\hline Bones & Lampblack \\
Bagasse & Leather waste \\
Bark & Municipal waste \\
Beat-sugar sludge & Molasses \\
Blood & Nut shells \\
Blue dust & News paper \\
Coal & Oil shale \\
Coffee beans & Olive stone \\
Coconut shell & Petroleum acid sludge \\
Coconut coir & Pulp mill waste \\
Cereals & Palm tree cobs \\
Carbohydrates & Petroleum cobs \\
Cottonseed hulls & Petroleum coke \\
Cottonseed hulls & Potassium ferrocyanide \\
& residue \\
Corn cobs & Rubber waste \\
Distillery waste & Rice hulls \\
Fertilizer waste slurry & Refinery waste \\
Fertilizer waste slurry & Scrap tires \\
Graphite & Sunflower seeds \\
Human hairs & Tea leaves \\
Lignin & Wheat straw \\
Jute stick & Wood \\
\hline
\end{tabular}


Table 4. Adsorption capacities $\mathrm{qm}(\mathrm{mg} / \mathrm{g})$ of different agricultural wastes for the contaminants.

\begin{tabular}{llll}
\hline Adsorbent & Adsorbate & $\begin{array}{l}\text { Maximum adsorp- } \\
\text { tion capacity (mg/g) }\end{array}$ & Reference \\
\hline Carrot residues & Cr(III) & 45.09 & Nasernejad et al. (2005) \\
& Cu(II) & 32.74 & \\
Orange peel & Zn(II) & 29.61 & Pehlivan et al. (2006) \\
& Cu(II) & 0.15 & \\
Banana peel & Zn(II) & 0.18 & Annadurai et al. (2002) \\
Rice husk & Basic blue 9 & 20.8 & Malik (2003) \\
Straw & Acid yellow 36 & 86.9 & Kannan and Sundaram (2001) \\
Banana stem & Basic blue 9 & 19.82 & Noeline et al. (2005) \\
Guava (Psidiumguajava) leaf & Ponnusami et al.(2008) \\
Powder & Pb(II) & 91.74 & \\
Peanut hull & blue & 185.2 & Gonget al. (2005) \\
Lemon peel & Methylene blue & 68.03 & Kumar and Porkodi (2006) \\
Peanut hull & Methylene blue & 29 & Tanyildizi (2011) \\
Maize cob & Reactive dye & 55.5 & \\
Wheat straw & 2,4-Dichlorophenol & 17.94 mg/g & Danget al. (2009) \\
Sunflower stalk & Cd(II) & 14.56 & Jalali and Aboulghazi. (2013) \\
\hline
\end{tabular}

Table 5. Adsorption capacities of different industrial wastes as adsorbents for the removal of various pollutants from water (Bhatnagar and Sillanpaa, 2010; Ahmaruzzaman, 2011).

\begin{tabular}{|c|c|c|c|c|}
\hline $\begin{array}{l}\text { S. } \\
\text { N. }\end{array}$ & Adsorbent & Adsorbate & $\begin{array}{l}\text { Adsorption } \\
\text { capacity }(\mathrm{mg} / \mathrm{g})\end{array}$ & Reference \\
\hline 1 & Fly ash & $\begin{array}{l}\text { Phenol, 3-chlorophenol } \\
\text { and 2,4-dichlorophenol }\end{array}$ & 67,20 and 22 & $\begin{array}{ll}\text { Akgerman, } & \text { M. } \\
\text { koohi,1996 } & \end{array}$ \\
\hline 2 & $\begin{array}{l}\text { Solid waste from } \\
\text { leather industry }\end{array}$ & $\mathrm{As}(\mathrm{V})$ and $\mathrm{Cr}(\mathrm{VI})$ & 26 and 133 & Oliveira et al., 2008 \\
\hline 3 & Biogas residual slurry & $\mathrm{Cr}(\mathrm{III})$ & 7.8 & $\begin{array}{l}\text { Namasivayam, R.T. Yamu- } \\
\text { na,1999 }\end{array}$ \\
\hline 4 & Red mud & $\mathrm{Cu}^{2+}, \mathrm{Zn}^{2+}, \mathrm{Ni}^{2+}$ and $\mathrm{Cd}^{2+}$ & $\begin{array}{l}\text { 19.72, } 12.59 \\
10.95 \text { and } 10.57\end{array}$ & Lópezet al.,,1998 \\
\hline 5 & Boron industry waste & $\begin{array}{l}\text { Basic yellow } 28 \text { and basic } \\
\text { red } 46\end{array}$ & 75.00 and 74.73 & Olgun and Atar, 2009 \\
\hline 6 & Activated slag & $\mathrm{Cu}, \mathrm{Ni}$ & $30.0,29.35$ & Gupta, 1998 \\
\hline 7 & Sludge & $\mathrm{Pb}^{2+}$ & 39.3 & Lister and Line, 2001 \\
\hline 8 & Lignin & $\mathrm{Cr}^{3+}$ & 17.97 & Guoet al., 2008 \\
\hline 9 & Tea industry waste & $\mathrm{Fe}^{3+}$ & 24 & Ahluwalia SS, Goyal, 2005 \\
\hline
\end{tabular}

2010). Various low cost adsorbents such as fruit wastes, coconut shell, scrap tyres, bark and other tannin-rich materials, sawdust and other wood type materials, rice husk, petroleum wastes, fertilizer wastes, fly ash, sugar mill wastes blast furnace slag, chitosan and seafood processing wastes, seaweed and algae, peat moss, clays, red mud, zeolites, sediment and soil, ore minerals etc. These adsorbents have been found to remove of various organic pollutants ranging from 80 to $99.9 \%($ Ali et al., 2012). The aim of this review is to provide the information regarding the use of low cost adsorbent such as agricultural waste and industrial waste materials as adsorbents for the removal of numerous toxic contaminants and heavy metals from paper mill wastewater. The review also presents and discusses various factors affecting the adsorption process.

Pulp and paper mill: During the twentieth century the population of the world has increased three folded, while the utilization of water has increased six folded of the population. Globally, irrigation is the largest user of water, followed by industrial use and domestic use (Cosgrove and Rijsberman, 2000). Meeting the increased demand for water, whilst keeping the fresh water eco systems of the world intact, is considered to be one of the biggest challenges of this century. One solution that has been discussed is to increase the reuse of water (Postel, 2000).

The pulp and paper industry is a growing sector that requires a large amount of water and energy. The main environmental issues are emissions to water and air, waste build-up and energy consumption (Suntio et al., 1988). The manufacturing of Pulp and paper with unit production capacities greater than 100 metric tons per day. As per the Ministry of Environment and Forest (MoEF), Government of India, the pulp and paper sector is in the "Red Category" list of 17 industries having a high polluting potential. Pulp and paper production is a major industry in India with a total capacity of over 3 million tons per annum (CPCB, 2001). 
Pulp and paper industries is considered as one of the most polluter industry in the world and are categorized by the occurrence of colour and suspended solids, organic and inorganic compounds, bad smell, high concentration of nutrients that cause eutrophication of receiving waters bodies, and high toxicity overall.Such effluents have the potential to adversely affect the receiving aquatic environment through, for instance, slime production by microorganisms such as Sphaerotilus sp. These factories commonly produce considerable amounts of wastewaters, especially from virgin raw materials processing and formation of scum, as well as toxicity to the exposed communities, thermal impacts, colour problems, and aesthetical issues (Pellegrin et al., 1999; Thompson et al., 2001; Lacorte et al., 2003; Pokhrel and Viraraghavan, 2004; Sumathi and Hung, 2006).

The pulp and paper mill produces large quantities of wastewater which needs suitable treatment prior to discharge in to the environment; otherwise it represents a significant consequence on the environment and health. The major challenging concern is the insistent dark brown colour due to lignin content and its derivatives, such as chloro lignin present in the effluent discharged from the pulp bleaching process (Prasongsuk et al., 2009). The potential recalcitrant compound which are released during the treatment of pulp and paper mill effluents that may the harmful effect on the environment and health (Table 1).

Characteristics of pulp and paper mill effluents: The pulp and paper mill effluent influenced by the type of manufacturing method used in the process and the extent of reuse of water recycled in industry. Effluent from kraft pulping is enormously polluted and categorized by parameters such as colour, adsorbable organic halides (AOX) and associated recalcitrant organic compounds. The major complications of pulp and paper mill effluent is the brown coloured effluent due to lignin and its derivatives. This effluent comes out from pulping, bleaching and chemical recovery phases. The brown colour of the effluent may increase water temperature and decrease photosynthesis, both of which may lead to reduce the concentration of dissolved oxygen of the water bodies (Bajpai et al., 1993; Ragunathan and Swaminathan, 2004) (Table 2).

Low cost adsorbants and their applications: Adsorption is one of the physico-chemical treatment technique found to be very effective for wastewater treatment because of its simplicity and cost effectiveness. Adsorbent can be measured as low-cost if it is rich in nature, needs slightly processing and is a by-product of waste substantial from waste industry. The common adsorbents include activated carbon, molecular sieves, polymeric adsorbents, and some other low-cost materials are inexpensive as they have no or very low economic value. With the convenience and cheapness of different adsorbent materials such as industrial by-products, agricultural wastes and other natural waste materialsused as low-cost adsorbenthas become popular now days. In adsorption process, thermodynamic and kinetic aspects should be elaborated to know more details about its concert and mechanisms. Except for adsorption capacity, kinetic concert of a given adsorbent is also the great importance for the pilot application (Qiu et al. 2009). In the process of adsorption, the gas liquid solute gathers on the adsorbent surface which forms a molecular film of the adsorbent. For the removal of metal ions and other recalcitrant compound from the industrial effluents, activated charcoal, synthetic resins, agricultural waste and industrial waste used as adsorbent followed by physical, biological, and chemical methods (Yadanaparthi et al., 2009, Kwon et al., 2010 and Gottipati et al., 2012).

Activated carbon: Activated carbon is the commonly preferred adsorbent; its widespread use is restricted due to high cost. The preparation and regeneration of low cost activated carbon in place of commercially available adsorbents. Several works has focused on various natural solid supports, which are able to remove pollutants from contaminated water using low cost activated carbon. Activated carbon is a crude form of graphite highly porous with variable pore sizes, noticeable cracks and crevices. Active carbon is prepared from coconut shells, wood char, lignin, petroleum coke, bone-char, peat, sawdust, carbon black, rice hulls, sugar, peach pits, fish, fertilizer waste, waste rubber tire, etc. (Mohan and Pittman, 2007) (Table 3).

Activated carbon has been shown to be an effective adsorbent for the color removal from the wastewater. Activated carbon in industrial treatments is more applicable with other technologies for example with Dissolved air flotation(DAF). DAF is used to remove the carbon from solution. Adsorption media cost and sludge production are factors limiting the application of this technology to the pulp paper industry. The carbon is activated usually by heat or chemical treatment; the adsorption is often so strong that the carbon has to regenerated or even discarded. (Diez et al. 1998 and Wingate. 2002). By chemical activation, activated carbon was prepared from paper mill sludge by using $\mathrm{K}_{2} \mathrm{CO}_{3}$. The results showed that the surface area at the experimental conditions is achieved to $908 \mathrm{~m}^{2} \mathrm{~g}^{-1}$. In addition to these advantages of preparation, the porous properties of activated carbon are outstanding because of the well-developed micro-pore. The adsorption isotherm data were fitted to two adsorption isotherm models and found to closely fit the Freundlich model with $\mathrm{R}^{2}$ equal 0.99 at $\mathrm{pH} 8$, indicating a multilayer of adsorption. Paper sludge is a promis- 
ing low cost precursor for the production of activated carbon and have the maximum retention capacity of the produced activated carbon was $280 \mathrm{mg} / \mathrm{g}$. (Nasr et al., 2017).

Agriculture waste materials: The utilization of agricultural waste material scan be seen as having a great potential to be developed and used as a low cost sorbent for the treatment of effluents from the various industries. The possibility of these materials could be beneficial not only for the environment in resolving the solid waste disposal problem, but also the economy useful for the wastewater treatment (Upadhye and Yamgar, 2016). Various agricultural waste materials as adsorbents are being studied for the removal of different dyes from aqueous solutions at different operating conditions (Table 4).Several agriculture waste materials are accessible in environment in which adsorption properties have been reported e.g rice husk, saw dust, tea and coffee waste, orange peel peanut shells, activated carbon, dry tree leaves and barks (Asma et al., 2005; Ferda and Selen, 2012; Kishore et al., 2008; Nuria et al., 2010).

The efficiency of sawdust in the removal of $\mathrm{Cu}^{2+}$ and $\mathrm{Zn}^{2+}$ ions was conducted by Sciban et al. (2006). The adsorption capacities were compared with the untreated sawdusts, poplar and firwood were treated with $\mathrm{NaOH}$ (fibre-swelling agent) and $\mathrm{Na}_{2} \mathrm{CO}_{3}$ solutions. After treating with $\mathrm{NaOH}$, increase in adsorption capacity was observed to be increase to 2.5 times for $\mathrm{Cu}^{2+}$ and 15 times for $\mathrm{Zn}^{2+}$. The adsorption capacities shown by Langmuir model were $6.92 \mathrm{mg} \mathrm{g}^{-1}$ (poplar sawdust) and $12.70 \mathrm{mg} \mathrm{g}^{-1}$ (fir sawdust) for $\mathrm{Cu}^{2+}$, and 15.83 $\mathrm{mg} \mathrm{g}^{-1}$ (poplar sawdust) and $13.41 \mathrm{mg} \mathrm{g} 1$ for $\mathrm{Zn}^{2+}$ (fir sawdust), respectively. Parabet al. (2006) observed the maximum adsorption capacity of coir pith was $12.82,11.56$ and $15.95 \mathrm{mg} / \mathrm{g}$ for cobalt, chromium and nickel, respectively. Optimum $\mathrm{pH}$ values for maximum metal ion adsorption were found as 4.3 for cobalt, 3.3 for chromium and 5.3 for nickel (Table 4).

By using Crude Pongamia Leaf Powder (CPLP) and modified with nitric acid Pongamia Leaf Powder (APLP) shows removal of $\mathrm{Cr}(\mathrm{VI})$ at $\mathrm{pH} 2.0$ and contact time 165 minutes. APLP was found to be more efficient than CPLP with an initial $\mathrm{Cr}(\mathrm{VI})$ concentration of $5 \mathrm{mg} / \mathrm{l}$ (Shivamani and Prince, 2008). Theivarasu and Mylsamy (2010)was studied the adsorption of Rhodamine-B dye using char prepared from the coconut shell with concentrated sulfuric acid at ratio of $1: 1(\mathrm{w} / \mathrm{v})$. The activation was executed by heating in a muffle furnace at $550{ }^{\circ} \mathrm{C}$ for 7 hours, followed by washing and drying. The treated coconut shell char was found $41.67 \mathrm{mg} / \mathrm{g}$ adsorption capacity. Kulkarni and Kaware (2015) have examined the removal of metal ions in a packed bed adsorption column using rice husk as cadmium sorbent. It was observed that increase in the initial cadmium concentration from $10 \mathrm{mg} / \mathrm{l}$ to $50 \mathrm{mg} / \mathrm{l}$ decreased exhaustion time from $830 \mathrm{~min}$ to $570 \mathrm{~min}$ and break point time decreased from $330 \mathrm{~min}$ to $120 \mathrm{~min}$. The adsorption efficiency was obtained as $69 \%$ for optimum conditions operating conditions (bed height, initial metal ion concentration, flow rate, and $\mathrm{pH}$ values) were found to be $50 \mathrm{~cm}, 30 \mathrm{mg} / \mathrm{l}, 60 \mathrm{ml} / \mathrm{min}$, and 6 , respectively (Table 4).

Industrial wastes and sludge as adsorbents: Widespread industrial activities produce huge amount of solid waste materials as by-products. Some of this material is being put to use while others find no proper utilization and are discarded in the different places. The industrial waste material is available without any cost and causes major disposal problem to the environment. If these industrial solid wastes could be used as low-cost adsorbents, the volume of waste materials and pollution load could be decreased at reasonable cost (Bhatnagar, M. Sillanpa, 2010). Various industrial wastes as adsorbent have been discovered with or without treatment as adsorbents for the removal of pollutants from wastewater. Mendezet al. (2009) studied the \% reduction of $\mathrm{Cu}^{2+}$ from water using adsorbent generated from paper industry waste (de-inking paper sludge and sludge from virgin pulp mill). Experimental results revealed that the adsorbent prepared from the virgin pulp is of microporous nature whereas the deinked sludge based adsorbent is microporous in nature. Adsorbent materials remained then used for $\mathrm{Cu}^{2+}$ reduction from water at acidic $\mathrm{pH}$. Final $\mathrm{pH}$ noticeably improved after treatment of water with adsorbent materials probably due to their raised $\mathrm{CaCO}_{3}$ content. In common, highest $\mathrm{Cu}^{2+}$ removal were attained using adsorbent prepared from de-inking paper sludge (Table 5).

Paper industry also produces black liquor, a waste product originated from paper industry, was examined for the adsorption of $\mathrm{Pb}^{2+}$ and $\mathrm{Zn}^{2+}$ by Srivastava et al. (1994). An adsorption capacity of 1865 and $95 \mathrm{mg} / \mathrm{g}$ was reported for $\mathrm{Pb}^{2+}$ and $\mathrm{Zn}^{2+}$, respectively, at $40 \circ \mathrm{C}$. The adsorption of phenols on paper mills sludges was studied by Calce et al. (2002). The retention capacity of paper mill sludges was observed in the order: 2-nitrophenol $=4$ nitrophenol_2-chlorophenol $<$ phenol $<4$ chlorophenol $\leq 3$-chlorophenol< 2,4-dichlorophenol $<3$,4-dichlorophenol = 2,4,5-trichlorophenol <3,5dichlorophenol.Papermill sludge was also examined for the removal of orange Gdye (an anionic dye) from aqueous solutions (Bhatnagar et al., 2007).

Aksu and Yener (1999) investigated the potential of fly ash as a alternate for activated carbon for phenol adsorption. At initial phenol concentration of $100 \mathrm{mg} / \mathrm{L}$, the maximum phenol adsorption efficiency was obtained $27.9 \mathrm{mg} / \mathrm{g}$ for fly ash and $108.0 \mathrm{mg} / \mathrm{g}$ for granular activated carbon. 


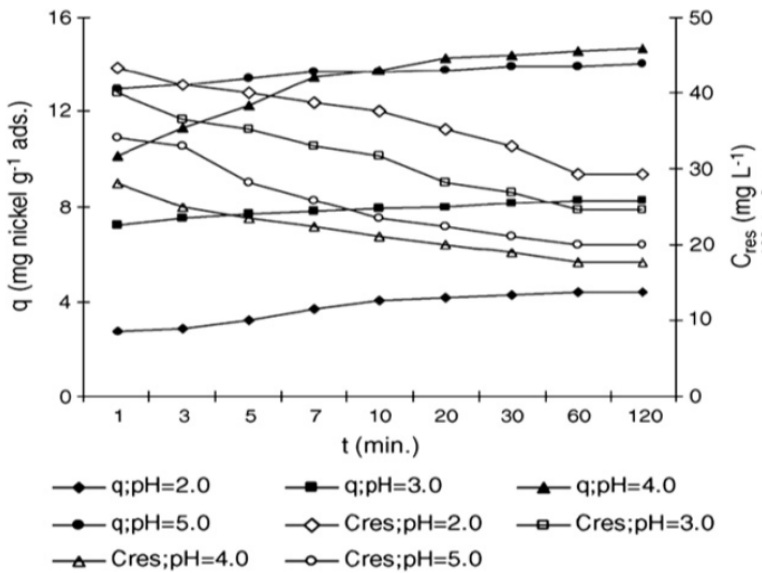

Fig. 1. Effect of $\mathrm{pH}$ on $\mathrm{Ni}(\mathrm{II})$ uptake and residual concentration by waste tea (adsorbentdosage $=10 \mathrm{~g} / \mathrm{L}$, agitating rate $=360 \mathrm{rpm}, \mathrm{CO}=100 \mathrm{mg} \mathrm{L}-1)$ (Malkoc $E$, Nuhoglu, 2005).

The effectiveness of fly ash in removal of phosphate from aqueous solution and its related mechanism was studied by Lu et al.(2009). Results disclosed that 68-96\% phosphate removal in the first $5 \mathrm{~min}$ by fly ash. This is due to fast kinetics and high removal on behalf of precipitation, then a slower and longer removal due to adsorption.

Dried activated sludge has been explored for the sorption of phenol, o-chlorophenol and pchlorophenol from aqueous solutions 1998. The maximum sorption capacity of dried activated sludge was found to be $86.1 \mathrm{mg} / \mathrm{g}$ for phenol, $102.4 \mathrm{mg} / \mathrm{g}$ for o-chlorophenol and $116.3 \mathrm{mg} / \mathrm{g}$ for $\mathrm{p}$-chlorophenol at $100 \mathrm{mg} / \mathrm{L}$ initial pollutant concentration. Selvaraj et al. (2003) examined the potential of distillery sludge for $\mathrm{Cr}(\mathrm{VI})$ removal and described the Langmuir adsorption capacity of 5.7 $\mathrm{mg} / \mathrm{g}$ for $\mathrm{Cr}(\mathrm{VI})$. Li et al. (2004) used wine processing waste sludge as an effective adsorbent for $\mathrm{Cr}$ (III) removal. Adsorption dynamics had been fruitfully described by the Lagergren model and intra particle diffusion model. The sewage treatment plant biosolids (sludge) was used as adsorbent in removing basic dyes, Basic blue 3,Basic red 22 and Basic black 9 from aqueous solutions (ZahangirAlam, 2004). Batch mode adsorption results are explored by varying different condition like contact time, initial dye concentration, adsorbent dose, agitation rate, temperature and $\mathrm{pH}$. The results indicated that the adsorption capacity of basic dyes was higher $(22-24 \mathrm{mg} / \mathrm{g})$ with the lower values of the temperature $\left(25-30^{\circ} \mathrm{C}\right)$, adsorbent dosage $(0.5-0.75 \% \mathrm{w} / \mathrm{v})$, higher values of the initial $\mathrm{pH}$ (8-9)and agitation rate (150-200 rpm). The equilibrium in the solution was observed within $2 \mathrm{~h}$ of operation (Table 5).

\section{Factors affecting the adsorption}

Effect of $\mathrm{pH}$ : The $\mathrm{pH}$ is the essential to the adsorption process and has precious not only adsorption capacity but also surface charge of the adsorbent, the degree of ionization of the chemis-

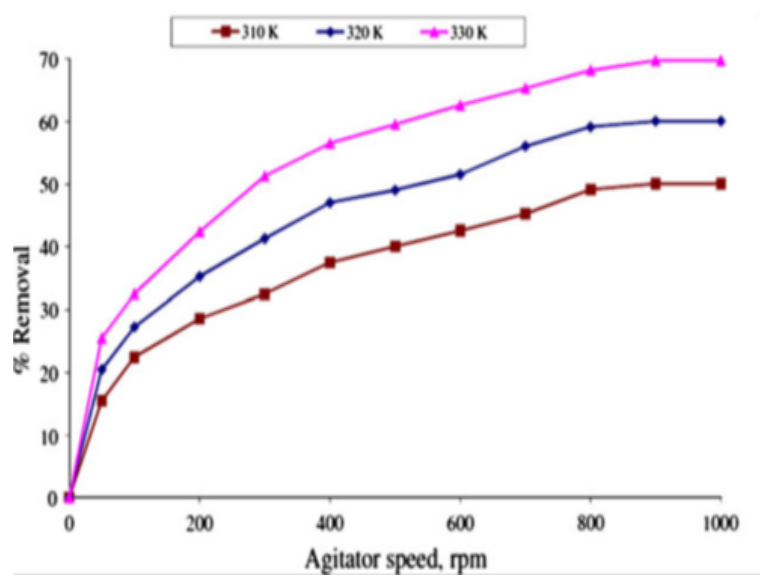

Fig. 2. Effect of agitation speed with various temperatures (Patel and Vashi, 2010).

try of the dye solution. Methylene blue (MB) has a pK value of 3.8 with the cationic properties of the dye and (Kimet al. 2013). The $\mathrm{H}+$ ions combine with the-ve charged adsorbent surface (oxides of aluminum, calcium, silicon, iron, etc.) and neutralize them (Devi et al., 2008)and thereby reduce the hindrance to the diffusion of organic molecules. The lower adsorption at higher $\mathrm{pH}$ might be possible due to the presence of $\mathrm{OH}$ - ions. These $\mathrm{OH}$ ions cause hindrance to the diffusion of organic (contributing to COD) ions (Das \& Patnaik, 2001). According to the mechanism and the discussion of $\mathrm{pH}$ effect, the adsorption will lead to a decrease in $\mathrm{pH}$ as equivalent $\mathrm{H}+$ will be released along with the adsorption. This is the case for most metal adsorption, but there is always exception. Some metals existing as negative species in solution, such as hexavalent chromium, may release hydroxide $\left(\mathrm{OH}^{-}\right)$instead of proton $(\mathrm{H}+)$ when they are adsorbed by waste materials, and therefore result in an increase in $\mathrm{pH}$. Fig. 1 indicated that the effect of $\mathrm{pH}$ on $\mathrm{Ni}$ (II) uptake and residual concentration by waste tea (Malkoc E, Nuhoglu, 2005). Hydrogen ion work as a spanning ligand between the adsorbent wall and the dye molecule (Aksu and Tezer, 2005).At high pH,decreases the positive charge at the solution interface and the adsorbent surface seems negatively charged (Özcan et al. 2007).

Effect of agitation speed and contact time: According to Farhan et al.(2013) reported that at lower time concentrations (1-4hrs), Cedrusdeodara shows very sharp decrease in color ranging from $56 \%$ to $100 \%$. Dalbergiasissoo has almost constant rate of reaction. Whereas Eucalyptus spp., show less reduction from 1-3hrs but reduction shoots up sharply at $4 \mathrm{hrs}$ time duration, further increase from $4 \mathrm{hrs}$ to $6 \mathrm{hrs}$ does not significantly increase color reduction. Gupta et al., (2011) also attained equilibrium of $60 \mathrm{~min}$ for Acid Blue 113 dye uptake. The decrease in dye reduc- 


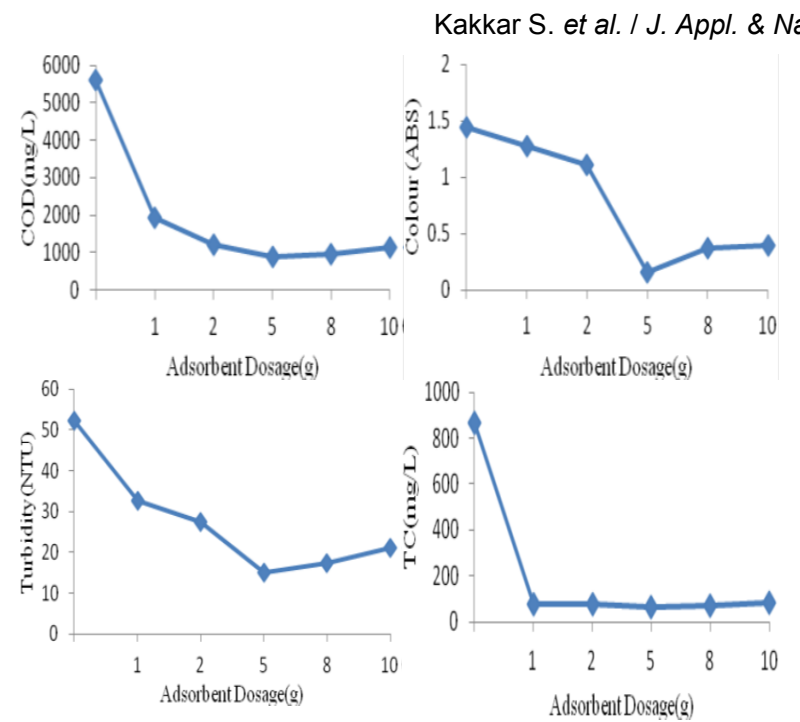

Fig.3. Effect of Adsorbent Dosage on COD, colour, turbidity and total carbon removal from the paper mill effluent (Shivayogimath and Joshi, 2015).

tion with time might be due to accumulation of dye molecules around the activated carbon. There will be no more reduction in COD, after the equilibrium point has reached. Infect at equilibrium the rate of adsorption of pollutant onto the activated carbon is almost equal to the rate of desorption (Mohan et al., 2008).

The effect of contact time carried out by using the adsorbent-adsorbate solution with fixed adsorbent dose and initial dye concentration for different time intervals and shaken until equilibrium. Generallyt he rate of removal of dye increases with an increase in contact time to a certain extended period.Further increase in contact time does not increase the reduction of dye due to deposition of dyes on the available adsorption site on adsorbent material (Ansari and Mosayebzadeh, 2010). Patel and Vashi (2010) described that the percentage of crystal violet adsorption increased up to $15.5-50.0,20.5-60.0$ and $25.5-69.7 \%$ respectively with increasing the agitation speed at 50-900 rpm and different temperatures (310, 320 and $330 \mathrm{~K}$ ), but then gradually approaches a constant value after $900 \mathrm{rpm}$ (Fig.2).

Effect of adsorbent dose: The three activated carbons differ significantly in their COD capacity. This decrease in COD uptake capacity with increase in dose of activated carbon may be due to the formation of clusters of carbon particles resulting in decreased surface area (Nagda, 2006). At low concentration, the interaction between solute and solvent increase, so the solute has low tendency towards activated carbon and high affinity towards solvent (Nadeem et al., 2006).Sharma and Uma (2010) conducted the experiment by taking different adsorbent doses $(0.40-0.60 \mathrm{~g})$ in $50 \mathrm{~mL}$ of dye solution in order to find the effect of different doses of rice husk cultivated carbon on the removal of methylene blue. The results showed that the removal increased from 86.75to $99.83 \%$ with increasing adsorbent dose from 0.40 to $0.60 \mathrm{~g}$ (fig. 3).

According to Uddin et al.,(2017) reported that the removal of dye was increased from 82 to $99 \%$ with an increase in adsorbent dose from 0.1 to $0.8 \mathrm{~g}$. The increase in the dye removal percentage with adsorbent dosages could be attributed to increase in the surface area of adsorbent. Adsorption capacity was decreased from 164 to $25 \mathrm{mg} / \mathrm{g}$ when the adsorbent dose was increased from 0.1 to 0.8 $\mathrm{g}$. The reduction in adsorption capacity qe $(\mathrm{mg} / \mathrm{g})$ with increasing adsorbent dose was due to the split in the flux or the concentration gradient between solute concentration in the solution and in the surface of the adsorbent.

Effect of particle size: Decrease inparticle size would lead to increase in surface area and then increase in the adsorption capacity at the outer surface of the waste materials. Besides adsorption at the outer surface of the waste material there is also adsorption of intra-particle diffusion from the outer surface into the pores of the material. Due to various factors, such as diffusional path length or mass transfer resistance, contact time and blockage of some diffusional path, most of the internal surface of the particle may not be utilized for adsorption; consequently the adsorption efficiency may become low (Ahmaruzzaman, 2011). Kulkarni et al., (2013) observed that as the particle size decreases from mesh number 36 to 72 , the percentage removal was increases. This is because of the increase in the surface area available for adsorption. The removal percent remains constant for the particle sizes finer than 72 mesh no. particles. The adsorbate is not able to utilize the extra surface area due to lack of contact with adsorbent .

Amarasinghe and Williams (2007) was studied the effect of particle size of tea waste on the adsorption capacity of heavy metals. The results showed that for tea waste particles of mean size 1250 , 925 and $575 \mu \mathrm{m}$, the removal of $\mathrm{Cu}$ ion were $41 \%$, $53 \%$ and $57 \%$ respectively. Batch adsorption experiments were also carried out to examine the effect of particle size of bagasse fly ash on the removal of $\mathrm{Pb}$ and $\mathrm{Cr}(\mathrm{VI})$ from their aqueous solution. The different particle sizes, 100-150, 200250 , and $300-350 \mu \mathrm{m}$ at $\mathrm{pH} 6.0$ for lead and 5.0 for chromium, with an adsorbent dose of $10 \mathrm{~g} / \mathrm{L}$, shaking time $80 \mathrm{~min}$ for lead and $60 \mathrm{~min}$ for chromium at $30{ }^{\circ} \mathrm{C}$. The adsorption of lead and chromium was found to be $99.9,95.0$, and $88.0 \%$, respectively using the above mentioned sizes (Gupta and Ali, 2004).

\section{Conclusion}

The pulp and paper industry is a complex activity which involves many different processes and products. Pollutants from the pulp and paper mill 
effluents are highly colored, mainly due to the presence of chromophoric compounds from wood extractives, lignin derivatives and organochlorine compounds, all recalcitrant. In this review various, low cost adsorbent such as agriculture waste product, activated carbon and industrial waste and sludge as adsorbent has been presented and also discussed the factor affecting the adsorption process. The use of these low-cost adsorbents suggests that these are the relatively cheap, easily available, renewable and show highly affinity for the removal of recalcitrant compounds from effluents of pulp and paper mills and the effluents from the various processes and operations of these industries. Adsorption is an innovative treatment option to improve the efficiency and increasing the possibility of discharge those wastewaters into the receiving bodies without causing any damage. Further research is to be focussed to make the process economically strong at industrial scale with the special reference to recovery of the metals and other recalcitrant compounds from the industrial wastewater.

\section{REFERENCES}

Ahluwalia, S.S. and Goyal D. (2005). Removal of heavy metals by waste tea leaves from aqueous solution. Eng. Life Sci. 5:158-162.

Ahmad AA, Hameed BH (2010). Fixed-bed adsorption of reactive azo dye onto granular activated carbon prepared from waste. J. Hazard. Mater., 175:298-303

Ahmaruzzaman, M. (2011).Industrial wastes as low-cost potential adsorbents for the treatment of wastewater laden with heavy metals.Advances in Colloid and Interface Science, 166: 36-59

Akgerman,A. and Zardkoohi, M. (1996).Adsorption of Phenolic Compounds on Fly Ash.J. Chem. Eng. Data, 41 (2): 185-187

Aksu Z. and Yener J. (1999). The usage of dried activated sludge and fly ash wastes in phenol biosorption/ adsorption: Comparison with granular activated carbon, J. Environ. Sci. Health Part A 34: 1777-1796.

Ali Imran, Asim M. And Khan Tabrez A. (2012). Low cost adsorbents for the removal of organic pollutants from wastewater. Journal of Environmental Management 113:170-183

Ali, Muna and Sreekrishnan T.R. (2001). Aquatic toxicity from pulp and paper mill effluents: a review. Advances in Environmental Research, 5: 175-196.

Amarasinghe, B.M.W.P.K. and Williams, R.A. (2007). Tea waste as a low cost adsorbent for the removal of $\mathrm{Cu}$ and $\mathrm{Pb}$ from wastewater.Chem. Eng. J. 132: 299 -309 .

Annadurai, G., R.S. Juang and D.J. Lee: Use of cellulose-based wastes for adsorption of dyes from aqueous solutions. J. Hazardous Materials, 92, 263-274 (2002)

Ansari, R. and Mosayebzadeh, Z. (2010). Removal of basic dye methylene blue from aqueous solutions using sawdust and sawdust coated with polypyrrole. J. Iran. Chem. Soc., 7: 339-350.

Area, M.C. and Valade, J.L. (1998).Revisión de losprocesos de pulpado con acciónquímica, El papel. La revistapapeleraparaEspeña y América Latina, 69:47-
51.

Asma.S, Muhammed, I, and Akhtar, M.W (2005) 'Removal and recovery of lead(II) from single and multimetal $(\mathrm{Cd}, \mathrm{Cu}, \mathrm{Ni}, \mathrm{Zn})$ solutions by crop milling waste (black gram husk)',. Journal of Hazardous Materials, B117: 65-73

Azimvand J. and Mirshokraie SA (2016) Assessment of physico-chemical characteristics and treatment method of Paper Industry Effluents : a review.International Research Journal of Applied and Basic Sciences, Vol, 10 (1): 32-43

Bajpai P, Mehna A and Bajpai PK. (1993).Decolorization of kraft bleach plant effluent with the white rot fungus Trametesversicolor.ProcessBiochem., 28:377-384.

Bhatnagar, A., Minocha, A.K., Jeon, B.-H., Park, J.M.and Lee, G. (2007). Adsorption of orange $G$ dye on paper mill sludge: equilibrium and kinetic modeling, Fresenius. Environ. Bull. 16 (2007) 99-103.

Bhatnagar. A and Sillanp. M (2010) 'Utilization of agroindustrial and municipal waste materials as potential adsorbents for water treatment- a review.'Chemical Engineering Journal, Vol.157, pp.277-296.

Calce, N., Nardi, E., Petronio, B.M. and Pietroletti M. (2002).Adsorption of phenols by papermillsludges. Environ. Pollut. 118: 315-319.

Cosgrove, W. J., and Rijsberman, F.R., (2000).World water vision: making water everybody's business. London: Earthscan Publications Ltd.

CPCB (2001). "Comprehensive industry document for large pulp and paper industry."COINDS/36/2000 2001,2001

Dang VBH, Doan HD, Dang-Vu T. and Lohi A (2009) Equilibrium and kinetics of biosorption of cadmium (II) and copper (II) ions by wheat straw. Bioresour Technol., 100:211-219

Das, C.P. and L.N. Patnaik.(2001). Use of industrial waste for reduction of COD from paper mill effluents. Ind. J. Environ. Health., 43(12): 21-27.

Devi, R., V. Singh and A. Kumar (2008). COD and BOD reduction from coffee processing wastewater using Avocado peel carbon. Biores. Technol., 99: 1853-60.

Diez, M. C., M. L. Mora, et al. (1998). Adsorption of Phenolic Compounds and Color from Bleached Kraft Mill Effluent Using AllophanicCompounds.Water Research33(1): 125-130.

D'Souza, D.T., R. Tiwari, A.K. Sah and C. Raghukumar, (2006). Enhanced production of laccase by a marine fungus during treatment of colored effluents and synthetic dyes. Enzyme Microb. Technol., 38: 504-511.

El-Ashtoukhy ESZ, Amin NK, Abdelwahab O (2008). Removal of lead (II) and copper (II) from aqueous solution using pomegranate peel as a new adsorbent. Desalination, 223(1):162-173.

Farhan, M., Wahid, A., Kanwal, A. and Bell, J.N.B. (2013).Synthesis of activated carbon from tree sawdust and its usage for diminution of color and cod of paper-mill effluents.Pak. J. Bot., 45(S1): 521-527

Ferda.G and Selen.S.D (2012) 'Adsorption study on orange peel: Removal of $\mathrm{Ni}(\mathrm{II})$ ions from aqueous solution' African Journal of Biotechnology, Vol.11, pp.1250-1258.

Gong R, Li M, Yang C, Sun Y. and Chen J (2005). Removal of cationic dyes from aqueous solution by adsorption on peanut hull.J. Hazard Mater., 121:247250

Gong R, Zhu S, Zhang D, Chen J, Ni S, Guan R (2008). Adsorption behavior of cationic dyes on citric acid 
esterifying wheat straw: kinetic and thermodynamic profile. Desalination 230:220-228

Gottipati Ramakrishna and Mishra Susmita, (2012). Application of response surface methodology for optimization of $\mathrm{Cr}(\mathrm{III})$ and $\mathrm{Cr}(\mathrm{VI})$ adsorption on commercial activated carbons, Research Journal of Chemical Sciences, 2(2):40-48.

Guo, X., Zhang, S.and Shan, XQ. (2008). Adsorption of metal ions on lignin. J Hazard Mater. 151(1):134-142.

Gupta VKand Ali I. (2004). Removal of lead and chromium from wastewater using bagasse fly ash--a sugar industry waste.J Colloid Interface Sci., 271(2):321-8

Gupta, V.K. (1998). Equilibrium Uptake, Sorption Dynamics, Process Development, and Column Operations for the Removal of Copper and Nickel from Aqueous Solution and Wastewater Using Activated Slag, a Low-Cost Adsorbent. Industrial and Engineering Chemistry Research, 37(1): 192-202

Gupta, V.K., B. Gupta, A. Rastogi, S. Agarwa and A. Nayak. (2011). A comparative investigation on adsorption performances of mesoporous activated carbon prepared from waste rubber tire and activated carbon for a hazardous azo dye-Acid Blue 113. J. Hazard. Mat., 186: 891-901

Jalali M andAboulghazi F (2013).Sunflower stalk, an agricultural waste, as an adsorbent for the removal of lead and cadmium from aqueous solutions. J Mater Cycles Waste Manag 15:548-555

Kamali, M. and Khodaparast, Z. (2015). Review on recent developments on pulp and paper mill wastewater treatment. Ecotoxicology and Environmental Safety, 114: 326-342

Kishore, K.K., Xiaoguang,M.,Christodoulatos, C. and Veera,M.B. (2008). Biosorption mechanism of nine different heavy metals onto biomatrix from rice husk. Journal of Hazardous Materials, 53:1222-1234.

Kulkarni S.J. and Kaware J.P. (2015). Analysis of Packed Bed Adsorption Column with Low Cost Adsorbent for Cadmium Removal.Int.J.of Thermal \& Environmental Engineering. 9 (1): 17

Kulkarni, S.J., Dhokpande S. R. and Kware J.P. (2013).Studies on flyash as an adsorbent for removal of various pollutants from wastewater.International Journal of Engineering research \& Technology, 2 (5):1190-1195

Kumar K.V. and Porkodi K.J. (2006) Relation between some two- and three-parameter isotherm models for the sorption of methylene blue onto lemon peel. $J$ Hazard Mater., 138:633-635

Kwon J.S., Yun S.T., Lee J.H., Kim S.O and Jo H.Y. (2010). Removal of divalent heavy metals (Cd, Cu, $\mathrm{Pb}$, and $\mathrm{Zn}$ ) and arsenic (III) from aqueous solutions using scoria: kinetics and equilibrium of sorption, $J$. of Hazard Mater, 174: 307-313.

Lacorte S., Latorre A., Barcelo D. , Rigol A., Malmqvist A. and Welander T. (2003). Organic compounds in paper-millprocess waters and effluents. Trends in Analytical Chemistry, 22,(10)

Li, Y.-S., Liu, C.-C.andChiou, C.-S. (2004). Adsorption of $\mathrm{Cr}$ (III) from wastewater by wine processing waste sludge. J. Colloid Interface Sci.. 273: 95-101.

Lister, S. K. and Line M. A. (2001). Potential use of sevage sludge and paper mill waste for bioadsorption of metals from polluted water ways.Bio. Tech., 79 (1): 35-39

López, E., Soto, B., Arias, M., Núnez, A., Rubinos, D., and Barral, M.T.(1998) Adsorbent properties of red mud and its use for wastewater treatment. Water Res. 32: 1314-1322.

Lu, S.G., Bai, S.Q., Zhu, L. and Shan, H.D. (2009).Removal mechanism of phosphate from aqueous solution by fly ash.J.Hazard.Mater. 161: 95-101.

Malik P.K. (2003). Use of activated carbons prepared from sawdust and rice-husk for adsorption of acid dyes: a case study of Acid Yellow 36. Dyes and Pigments, 56,(3): 239-249

Malkoc, E. and Nuhoglu, Y. (2005): Investigations of $\mathrm{Ni}$ (II) removal from aqueous solutions using tea factory waste. J. Haz. Mater., 127: 120-128.

Mendez, A., Barriga, S., Fidalgo, J.M. and Gasco, G. (2009). Adsorbent materials from paper industry waste materials and their use in $\mathrm{Cu}$ (II) removal from water, J. Hazard. Mater.165: 736-743.

Mohan, D. and Pittman Jr. C. U (2007). Arsenic removal from water/wastewater using adsorbents-A critical review. Journal of Hazardous Materials, 142:1-53

Mohan, D., P.S. Kunwar and K.S. Vinod. (2008). Wastewater treatment using low cost activated carbons derived from agricultural byproducts-A case study. J. Hazard. Mat., 152: 1045-1053

Monte, M.C., Fuente, E., Blanco, A. and Negro, C. (2009).Waste management from pulp and paper production in the European Union. WasteManag., 29: 293-308.

Kannan,N. and M.M. Sundaram (2001). Kinetics and mechanism of removal of methylene blue by adsorption on various carbons-a comparative study. Dyes Pigments, 51: 25-40.

Nadeem, M., A. Mahmood, S.A. Shahid, S.S. Shah, A.M. Khalid and G. McKay.(2006). Sorption of lead from aqueous solution by chemically modified carbon adsorbents.J. Hazard. Mat., B138: 604-13

Nagda, G.K., V.S. Ghole and A.M. Diwan.( 2006). Tendu leaves refuse as biosorbent for COD removal from Molasses fermentation based bulk drug industry effluent. J. Appl. Sci. Environ. Mgt., 10 (3): 15-20.

Namasivayam, C. and Yamuna, R.T.(1999). Studies on chromium (III) removal from aqueous solution by adsorption onto biogas residual slurry and its application to tannery wastewater treatment.Water Air Soil Pollut. 113:371-384

Nasernejad, B., Zadeh, T.E., Pour, B.B., Bygi, M.E., Zamani, A., 2005. Comparison for biosorptionmodeling of heavy metals ( $\mathrm{Cr}(\mathrm{III}), \mathrm{Cu}(\mathrm{II}), \mathrm{Zn}(\mathrm{II}))$ adsorption from wastewater by carrot residues. Process Biochem. 40, 1319-1322.

Nasr, J. B., Hamdi N. and Elhalouani F. (2017). Characterization of activated carbon Prepared from sludge paper for methylene blue adsorption Journal of Materials and Environmental Sciences 8 (6): 1960-1967

Nemerow NL (2007) Industrial waste treatment. In: Nemerow NL (2007) Contemporary Practice and Vision for the Future.ButterWorth Heinemann, Elsevier Inc, UK.

Noeline, B.F., Manohar, D.M., Anirudhan, T.S., (2005). Kinetic and equilibrium modeling of lead(II) sorption from water and wastewater by polymerized banana stem in a batch reactor. Sep. Purif. Technol. 45, 131-140

Nuria, M., Cesar, V., Ignasi, C., Maria, M. and Antonio, F. (2010) 'Cadmium and lead Removal from Aqueous Solution by Grape Stalk Wastes: Modeling of a Fixed Bed Column' Journal of Chemical Engineering Da- 
ta,.55: 3548-3554.

Olgun, A. and Atar, N.(2009). Equilibrium and kinetic adsorption study of Basic Yellow 28 and Basic Red 46 by a boron industry waste, J. Hazard. Mater. 161:148-156.

Oliveira, D.Q.L., Gonc, M., alves, Oliveira, L.C.A. and Guilherme.L.R.G (2008). Removal of $\mathrm{As}(\mathrm{V})$ and $\mathrm{Cr}$ (VI) from aqueous solutions using solid waste from leather industry. J. Hazard. Mater.151: 280-284

Özcan A., Ömeroglu Ç., Erdogan Y., Özcan A.S. ( 2007). Modification of bentonite with a cationic surfactant: an adsorption study of textile dye Reactive Blue 19. J. Hazard.Mater. 140: 173-179.

Parab, H., Joshi, S., Shenoy, N., Lali, A., Sarma, U. S., and Sudersanan, M., 2006, Determination of kinetic and equilibrium parameters of the batch adsorption of $\mathrm{Co}(\mathrm{II}), \mathrm{Cr}(\mathrm{III})$ and $\mathrm{Ni}(\mathrm{II})$ onto coir pith, Process Biochemistry, 41 (3), 609-615.

Patel, H.and Vashi R.T. (2010). Adsorption of Crystal Violet Dye onto Tamarind Seed Powder.E-Journal of Chemistry, 7(3):975-984

Pehlivan, E., Cetin, S., Yanık, B.H., (2006). Equilibrium studies for the sorption of zinc and copper from aqueous solutions using sugar beet pulp and fly ash. J. Hazard. Mater. B 135, 193-199

Pellegrin, V., Juretschko, S., Wagner, M. and Cottenceau, G., (1999). Morphological and biochemical properties of a Sphaerotilu ssp. Isolated from paper mills limes. Appl. Environ. Microbiol. 65:156-162.

Pokhrel, D. and Viraraghavan, T., (2004).Treatment of pulp and paper mill wastewater - a review.Sci. Total Environ. 333: 37-58.

Ponnusami.V,Vikram.S.N and Srivastava, (2008) 'Guava (Psidiumguajava) leaf powder: novel adsorbent for removal of mehtylene blue from aqueous solutions' Journal of Hazardous Materials, Vol. 152, pp.276-286.

Postel, S.J. (2000). Entering an era of water scarcity: The challenges ahead.Ecological Applications: 941948.

Prasongsuk, S., P. Lotrakul, T. Imai and H. Punnapayak, (2009).Decolourization of pulp mill wastewater using thermotolerant white rot fungi.Sci. Asia, 35: 37-41

Qiu, H., Lu LV, Bing-cai PAN†‡, Qing-jian ZHANG, Weiming ZHANG, Quan-xing ZHANG (2009). Critical review in adsorption kinetic models.J Zhejiang UnivSci A, 10(5):716-724

Rafatullah M., Sulaiman O., Hashim R. and Ahmad A. (2010). Adsorption of copper (II) onto different adsorbents. Journal of Dispersion Science and Technology, 31(7): 918-930.

Ragunathan R, Swaminathan K. (2004). Biological treatment of pulp and paper industry effluent by Pleurotus spp. World J of Micro and Biotech 20:389-393.

ScibanM , Klasnja M . andSkrbić B (2006).Modified softwood sawdust as adsorbent of heavy metal ions from water.Journal of Hazardous Materials, 136 (2):266-271

Selvaraj, K., Manonmani, S., Pattabhi, S. (2003). Re- moval of hexavalent chromium using distillery sludge, Bioresour. Technol. 89: 207-211.

Sharma, Y.C. and Uma, (2010). Optimization of parameters for adsorption of methylene blue on a low cost activated carbon. J. Chem. Eng. Data 55: 435

Shivamani, S and Prince I., V (2008).Batch adsorption studies for chromium Removal. Journal of Environmental Science and Engineering, 50(1): 11-16.

Shivayogimath, C. B. and Joshi C. (2015). Removal of organic pollutants from paper and pulp effluent using mixed adsorbents. International Journal of Advances in Science Engineering and Technology, 3 (3) 109113

Srivastava, S.K., Singh, A.K.and Sharma A. (1994). Studies on the uptake of lead and zinc by lignin obtained from black liquor-a paper industry waste material. Environ. Technol. 15: 353-361.

Sumathi, S. \& Hung, Y.T. (2006). Treatment of pulp and paper mill wastes, In: Waste treatment in the process industries. Eds: Wang, L.K, Hung, Y.T., Lo, H.H., Yapijakis,C. pp. 453-497. Taylor\& Francis. ISBN 08493-7233-X, USA.

Suntio, L.R., Shiu, W.Y., Mackay, D. (1988) A review of the nature and properties of chemicals present in pulp mill effluents. Chemosphere 17: 1249-1290.

Tanyildizi, M.S., (2011). Modeling of adsorption isotherms and kinetics of reactive dye from aqueous solution by peanut hull.Chem. Eng. J.,168:1234-1240

Theivarasu and Mylsamy (2010). Adsorption of anionic dyes in acid solutions using chemically cross-linked chitosan beads. Dyes Pigments, 60: 69-84

Thompson, G., Swain, J., Kay, M. and Forster, C. (2001). The treatment of pulp and paper mill effluent: a review. Bioresource Technology, 77: 275-286.

Uddin, T. Md., Arifur Rahman, Md. Rukanuzzaman, Md. And Akhtarul Islam, Md. (2017). A potential low cost adsorbent for the removal of cationic dyes from aqueous solutions.Appl Water Sci., DOI 10.1007/ s13201-017-0542-4

United Nations (2011).Department of economic and Social Affairs, Population Division, 2011. World Population Prospects: the 2010 Revision, Highlights and Advance Tables. ESA/P/WP.220

Upadhye, G.C. and Yamgar, R.S. (2016).Analytical study of agricultural waste as nonconventional low cost adsorbent removal of dyes from aqueous solutions.International Journal of Chemical Studies, 4(1): 128-133

Wingate, K. G. (2002). Novel Methods for Removal of Colour from pulp Mill Wastwater.Chemistry Auckland, University of Auckland.

Yadanaparthi S.K.R., Graybill D. and Wandruszka R. (2009), Adsorbents for the removal of arsenic, cadmium, and lead from contaminated waters, J. of Hazard Mater., 171: 1-15.

Zahangir Alam M. (2004).,Biosorption of Basic Dyes using sewage treatment plant biosolids, Biotechnology, 3(2), 200-204 